done from the top downwards. Although obvious air bubbles were eliminated, small bubbles in the interior of the dialyser could not be seen. Thus it seems probable that more gas (and hence conceivably residual ethylene oxide) remained within the dialyser with this technique.

We immediately rectified our technique, and no new patients developed the syndrome subsequently. None the less, three patients continued to have symptoms whenever they used a new disposable dialyser.

\section{Conclusion}

Although we have no absolute proof, we suggest that the following sequence of events may have occurred. Incorrect priming of the dialysers resulted in small amounts of ethylene oxide or some other easily removed substance remaining in small gas bubbles in the dialyser. This gradually sensitised some patients, who subsequently reacted to trace amounts in blood returning from incorrectly primed dialysers but were not affected by dialysers sterilised with formalin. Three patients became so sensitive that they continued to react to the even smaller amounts of ethylene oxide inevitably diffusing out of a dialyser despite proper preparation. An allergic reaction to ethylene oxide bound to albumin has been described previously.

This explanation is not, however, entirely satisfactory. We do not understand why these attacks appeared in an epidemic fashion in 1981, when there had been no obvious change in the technique of priming dialysers over the previous five years. The reactions were not attributable to faults in the manufacture or sterilisation of the dialysers since the products of four different firms were involved simultaneously.

We are grateful to Extracorporeal Ltd for the time, trouble, and expense expended by them in attempts to solve our problem. We continue to use their flat plate dialysers with confidence.

ADDENDUM-Since we submitted this paper a further patient who had not previously reacted to dialysis developed sneezing, wheezing, watery eyes, and urticaria within a minute of connection to a disposable flat plate dialyser. The dialyser had been properly primed in hospital. This further case strengthens our belief that incorrect priming of dialysers was not the sole cause of this syndrome.

\section{References}

1 Aljama P, Brown P, Turner P, Ward MK, Kerr DNS. Haemodialysistriggered asthma. $\mathrm{Br}$ Med $\mathcal{F} 1978$;ii :251-2.

${ }^{2}$ Hanai KEI, Horinchi T, Hanai J, et al. Hemodialysis-associated asthma in a renal failure patient. Nephron $1979 ; 25: 247-8$.

${ }^{3}$ Craddock PR, Fehr J, Dalmasso AP, Brigham KL, Jacob HS. Hemodialysis leukopenia. $\mathcal{F}$ Clin Invest 1979;59:879-88.

${ }^{4}$ Robinson PJA, Rosen SM. Pyrexial reactions during haemodialysis. Br Med f 1971 ;i:528-30.

${ }^{5}$ Neugebauer E, Lorenz W. Histamine in health and disease. Behringer Institute Mitteilungen $1981 ; 68: 102-33$.

6 Petersen NJ, Carson LA, Favero MS. Bacterial endotoxin in new and reused hemodialysers: a potential cause of endotoxemia. Trans Am Soc Artif Intern Organs $1981 ; 27: 155-9$.

${ }^{7}$ Poothullil J, Shimizu A, Day RP, Dolovich J. Anaphylaxis from the product(s) of ethylene oxide gas. Ann Intern Med 1975;82:58-60.

(Accepted 28 October 1982)

\title{
Haemophilia and the kidney: assessment after 11-year follow-up
}

\author{
M SMALL, P E ROSE, N McMILLAN, J J F BELCH, E B ROLFE, C D FORBES, J STUART
}

\begin{abstract}
Radiological and biochemical investigations of renal function were performed in 57 patients with haemophilia, 27 of whom had been previously investigated in 1969 . Although one-third of patients had a renal radiographic abnormality, only two had abnormalities persisting since 1969 and attributable to renal bleeding. Isotope renography was a sensitive indicator of renal abnormality whereas a history of haematuria was a poor discriminator for patients with abnormal intravenous urograms or impaired creatinine clearance. Haematuria was not associated with progressive loss of renal function and its natural history in haemophilia is probably benign.
\end{abstract}

\footnotetext{
University Department of Medicine and Department of Radiology, Royal Infirmary, Glasgow G4 OSF

M SMALL, MB, MRCP, registrar in medicine

N MCMILLAN, MB, DMRD, senior registrar in radiology

$\mathrm{J} J$ F BELCH, MB, MRCP, honorary registrar in medicine (presently lecturer in rheumatology, Centre for Rheumatic Diseases, Glasgow)

C D FORBES, MD, FRCP, senior lecturer in medicine
Departments of Haematology and Radiology, Queen Elizabeth Hospital, Birmingham B15 2TH
P E ROSE, MB, MRCP, senior registrar in haematology
E B ROLFE, BSC, FRCR, consultant radiologist

J STUART, MD, FRCPATH, professor of haematology
}

\section{Introduction}

Urinary tract bleeding is the most common manifestation of haemophilia after haemarthrosis. ${ }^{1}$ In addition, $20 \%$ of asymptomatic patients have subclinical microscopical haematuria. ${ }^{2}$ Several studies have also shown a high incidence of renal abnormalities in haemophilia, both by biochemical tests and by intravenous urography. ${ }^{2-5}$

In 1969 our two haemophilia centres (Glasgow and Birmingham) separately investigated ${ }^{2} 3$ two groups of patients with haemophilia with radiographic renal abnormalities (incidences of $38 \%$ and $36 \%$ respectively). It is clearly important to know whether these abnormalities were transient and of no long-term clinical importance or whether progressive renal damage has subsequently occurred. Renal function was therefore reassessed biochemically and radiologically in 27 patients from the two centres 11 years after the initial investigations. In addition, we have investigated a new series of 30 haemophiliacs adequately treated on demand or by self-therapy for at least five years to determine if the incidence of renal abnormalities has decreased as a consequence of more active treatment.

\section{Patients and methods}

Follow-up since 1969-Any change in renal function since 1969 was assessed in the 27 patients by the following investigations: (a) history of haematuria over the past five years graded as ++ -haematuria exceeding a collective total of three weeks or requiring two or more hospital admissions or both, + -haematuria of less than a total of three weeks or requiring one hospital admission or both, 0 -no clinical 
haematuria; (b) analgesic consumption; (c) blood pressure after 15 minutes sitting at rest (a diastolic pressure of $>100 \mathrm{~mm} \mathrm{Hg}$ was considered abnormal); (d) urine analysis by chemical tests (Labstix, Ames) for haematuria/proteinuria, microscopy, and culture; (e) serum urea, creatinine, and electrolyte values and a 24-hour urine sample for creatinine clearance (a creatinine clearance of $>80 \mathrm{ml} / \mathrm{min}$ was considered to be normal); $(f)$ intravenous excretion urogram; and $(g)$ isotope renogram with dynamic imaging using a Searle gamma camera (patients were imaged for 25 minutes after injection of $4 \mathrm{mCi}$ of ${ }^{99} \mathrm{Tc}$-labelled diethylene triamine pentacetic acid).

New patients-Thirty additional patients with haemophilia A were similarly investigated (table I). Fourteen of these patients (12 with

TABLE I-Clinical details of haemophilia in 27 patients followed up since 1969 and 30 new patients

\begin{tabular}{lcc}
\hline Clinical details & $\begin{array}{c}\text { No of patients } \\
\text { followed up } \\
\text { since } 1969\end{array}$ & $\begin{array}{c}\text { No of new } \\
\text { patients }\end{array}$ \\
\hline Total No with haemophilia*: & 27 & 30 \\
Severe (factor concentration $<1 \mathrm{U} / \mathrm{dl}$ ) & 17 & 12 \\
$\quad$ Moderate (factor concentration $<5 \mathrm{U} / \mathrm{dl})$ & 6 & 4 \\
$\quad \begin{array}{l}\text { Mild (factor concentration }>5 \mathrm{U} / \mathrm{dl}) \\
\text { Factor concentration }(\mathrm{U} / \mathrm{dl}):\end{array}$ & 4 & 14 \\
$\quad \begin{array}{l}\text { Mean } \\
\text { Range }\end{array}$ & 5 & 8 \\
Age (years): & $<1-13$ & $<1-40$ \\
Mean \\
Range & $42 \cdot 9$ & $30 \cdot 4$ \\
& $21-68$ & $18-70$
\end{tabular}

* 25 of the 27 patients in 1969 and all new patients had haemophilia A (factor VIII deficiency).

severe and two with moderate haemophilia) were receiving selftreatment while 16 moderately or mildly affected patients had been treated with factor VIII concentrate on demand. The minan age of this group was similar to that of the initial group studied 11 years before. All patients were free from haematuria at the time of study.

Statistical analysis-The incidence of abnormality between patient groups was analysed using the $\chi^{2}$ test.

\section{Results}

\section{FOLLOW-UP SINCE 1969}

The results for 1980 are summarised in table II.

Haematuria-The relationship of clinical haematuria in 18 of the 27 $(67 \%)$ patients to abnormalities detected by intravenous urography and creatinine clearance is shown in table III. Since patients have difficulty in recalling episodes of haematuria, estimates of mild haematuria are probably underrecorded. The history of haematuria in individual patients also varied with time: haematuria had developed, or increased in severity, in some patients while in others haematuria which had been severe 11 years ago had become mild or disappeared altogether. Overall, haematuria was a less prominent complaint than 11 years previously.

Analgesic consumption-Nineteen of $27(70 \%)$ patients were regularly taking analgesics, usually dihydrocodeine and paracetamol, but no evidence of analgesic nephropathy was found.

TABLE II-Comparison of results obtained in 1980 for the 27 patients followed up since 1969 and the 30 new patients

\begin{tabular}{|c|c|c|}
\hline & $\begin{array}{l}\text { No }(\%) \text { of patients } \\
\text { followed up since } \\
1969(\mathrm{n}=27)\end{array}$ & $\begin{array}{l}\text { Nuve (n) of nicw } \\
\text { patients }(n=30)\end{array}$ \\
\hline $\begin{array}{l}\text { Self treatment } \\
\text { Haematuria }\end{array}$ & $9(33)$ & $14(47)$ \\
\hline Total No & $18(67)$ & $12 *(40)$ \\
\hline $\begin{array}{l}\text { Severe }(t+) \\
\text { Mild }(t)\end{array}$ & $17(4)$ & 1 (3) \\
\hline None (0) & $9(33)$ & $18(60)$ \\
\hline Analgesic consumption & $19(70)$ & $3 * *(10)$ \\
\hline Hypertension (diastolic $>100 \mathrm{~mm} \mathrm{Hg}$ ) & $3(11)$ & $1 \quad(3)$ \\
\hline $\begin{array}{l}\text { Creatinine clearance ( }<80 \mathrm{ml} / \mathrm{min}) \\
\text { Abnormal intravenous urogram (total No }\end{array}$ & $6.26(23)$ & $3 / 25 \quad$ (12) \\
\hline $\begin{array}{l}\text { including } 1 \mathrm{CT} \text { scan) } \\
\text { Congenital anomalies }\end{array}$ & $\begin{array}{r}10(37) \\
3(11)\end{array}$ & $\begin{array}{ll}5 & (17) \\
2 & (7)\end{array}$ \\
\hline
\end{tabular}

$\mathrm{p}<0.05 ;{ }^{* *} \mathrm{p}<0.001$
Blood pressure-Three patients were mildly hypertensive and one, $\stackrel{\underline{m}}{\longrightarrow}$ having taken a beta-blocker for three years, had electrocardiographic 3

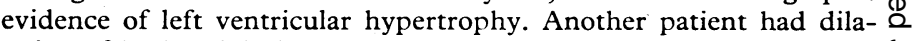
tation of both pelvicalyceal systems with delayed excretion from the $c$ left kidney on renography.

Urinalysis-No patient had proteinuria or evidence of infection. $\overline{\bar{J}}$

Urea, electrolyte, and creatinine clearance values-Serum urea $D$ concentrations were within normal limits in all 27 patients and serum $\Phi$ creatinine concentrations were increased in one. In 26 patients creati- m nine clearance was abnormal in six $(23 \%)$. One patient, with a clearance of $45 \mathrm{ml} / \mathrm{min}$, had developed haematuria while taking antifibrinolytic treatment and had been temporarily anuric. Of the $11 \stackrel{?}{?}$ patients in whom an 11-year comparison of creatinine clearance was $\bar{O}$ obtained, the values in eight remained unchanged (two were low at $\frac{}{\partial}$ $73 \mathrm{ml} / \mathrm{min}$ and $76 \mathrm{ml} / \mathrm{min}$ ) and three had fallen appreciably. Of these $\overline{\bar{\omega}}$. three patients, two had urographic appearances which were normal $\overrightarrow{\mathbb{D}}$ and unchanged. The third patient, who in 1969 was found to have a $\varrho$ mild right-sided filling defect with a clearance of $140 \mathrm{ml} / \mathrm{min}$, had developed a displaced left kidney probably due to haematoma $\vec{\circ}$ formation; his creatinine clearance rate had fallen to $52 \mathrm{ml} / \mathrm{min}$.

TABLE III-Relationship of haematuria to abnormalities detected by intravenous urography and to creatinine clearance rates in the 27 patients followed up since 1969

\begin{tabular}{lccc}
\hline Haematuria & No of patients & $\begin{array}{c}\text { No of patients } \\
\text { with abnormal } \\
\text { intravenous } \\
\text { urograms }\end{array}$ & $\begin{array}{c}\text { No of patients } \\
\text { with abnormal } \\
\text { creatinine } \\
\text { clearance rates }\end{array}$ \\
\hline $\begin{array}{l}\text { Severe } \\
\text { Mild }\end{array}$ & 1 & 0 & 0 \\
None & 17 & 5 & $0^{*}$ \\
& 9 & 4 & 2
\end{tabular}

* Of these 17 patients a further four had a normal intravenous urogram but an abnormal creatinine clearance rate.

Intravenous urography-In 1969, 10 of 27 intravenous urograms $\underset{\oplus}{\mathscr{\varphi}}$ showed abnormalities (table IV) but only in three patients (cases 1-3) ! did the abnormalities persist in 1980 . The patient in case 2 , who had $\square$ bilateral hydronephrosis in 1969, was found to have retroperitoneal fibrosis in 1980. Radiological changes in two patients (cases 1 and 3), however, were presumably a consequence of renal tract bleeding. Of 17 patients without radiological abnormalities in 1969, five had new $\stackrel{0}{8}$ abnormalities detected in 1980; these included two cases of fullness $\mathbb{Q}$ of the pelvicalyceal systems, one pseudotumour of the kidney, one $\overrightarrow{\vec{B}}$ renal cyst, and one small kidney. In total, 10 abnormalities were noted $\frac{9}{3}$ in 1980 , nine of which were probably attributable to renal tract bleeding.

Isotope renography was performed in 16 of the 27 patients, and in nine of the $16(56 \%)$ there was an impaired excretion curve for one or both kidneys. Renal function, as measured by creatinine clearance, was normal in eight out of nine of these patients. All patients 0 with an abnormal intravenous urogram also had an abnormal reno- 3 . gram. Furthermore, one patient, who in 1969 had right pelvicalyceal dilatation, had pronounced impaired drainage of the right collecting $\frac{3}{3}$ system on renography while the review urogram was normal. Two other patients had abnormal renograms with normal intravenous $\frac{\circ}{\partial}$ urograms.

\section{NEW PATIENTS}

Of the 30 new patients, including 14 of the more severely affected $O$ patients (table I) who were receiving home treatment, $12(40 \%)$ gave a

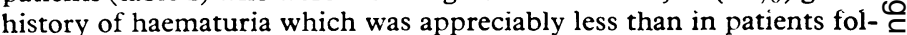

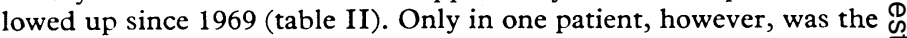
haematuria severe; this patient had normal urea and electrolyte values ? and no radiographic abnormalities. Appreciably fewer of the new patients (three in total) took analgesics regularly and one had uro- $\frac{\text { Oे }}{\mathbb{D}}$ graphic evidence of analgesic nephropathy. He was a 28 -year-old man $\subseteq$ with severe haemophilia and pronounced arthropathy who consumed $\stackrel{\mathbb{Q}}{\varrho}$ at least 20 dihydrocodeine tablets $(30 \mathrm{mg})$ a week. He had a history of $\sigma$ mild haematuria but his renal function remained normal. One patient had mild hypertension controlled by propranolol and bendrofluazide. Urine analysis, culture, and serum urea and electrolyte values were within normal limits in all 30 patients. Creatinine clearance rates 
measured in 25 patients were abnormal in three $(12 \%)$; two of these had urographic abnormalities (renal cyst and shrunken kidney due to pyelonephritis) and gave a history of mild haematuria while the remaining patient gave no history of haematuria and no radiological abnormality was noted. Although urographic abnormalities (table II) were detected in a total of five $(17 \%)$ patients, in two of these the abnormalities (chronic pyelonephritis and analgesic nephropathy) were unlikely to have been due to the effects of bleeding into the urinary tract. Therefore only $10^{\prime} \%$ had an abnormality likely to be associated with haemophilic bleeding. The creatinine clearance rates were hypertension only one had evidence of target organ damage, indicated by left ventricular hypertrophy.

In 1969 abnormal intravenous urograms were found in $36-38 \%$ of cases, and in our 11-year follow-up of the same patients $37 \%$ again had abnormalities. Only two abnormalities attributable to renal tract bleeding have persisted, however, for more than 11 years, and these patients have retained normal renal function. In previous studies it has been assumed that the incidence of renal abnormalities would increase with the

TABLE IV-Results of follow-up intravenous urography in the 10 patients with abnormal findings in 1969

\begin{tabular}{|c|c|c|c|c|}
\hline \multirow[b]{2}{*}{ Case No } & \multirow{2}{*}{$\begin{array}{l}\text { Haemophilia factor } \\
\text { VIII IX } \\
\text { (U /dI) }\end{array}$} & \multirow{2}{*}{$\begin{array}{l}\text { Creatinine } \\
\text { clearance } \\
(\mathrm{ml} \text { min })\end{array}$} & \multicolumn{2}{|c|}{ Results of intravenous urography in: } \\
\hline & & & 1969 & 1980 \\
\hline 1 & 4 & 90 & Left pelvicalyceal dilatation & Left pelvicalyceal dilatation \\
\hline 2 & $<1$ & 88 & Bilateral hydronephrosis & Retroperitoneal fibrosis \\
\hline 3 & 1 & 87 & Right pelviureteric dilatation & Right hydronephrosis* \\
\hline 4 & 1 & 87 & Left pelvicalyceal dilatation & Right pelvicalyceal dilatation \\
\hline 5 & 13 & 52 & Right calyx clot & Left kidney displaced \\
\hline 6 & 6 & 109 & Right pelviureteric dilatation & Normal \\
\hline 7 & 6 & 114 & Right dilated ureter & Normal \\
\hline 8 & 1 & 111 & Right calyceal clubbing & Normal \\
\hline 9 & 1 & 112 & Ureteric clot & Normal \\
\hline 10 & $\therefore 1$ & 81 & Ureteric clot & Normal \\
\hline
\end{tabular}

* This patient, allergic to Hypaque, had a computed tomography scan performed rather than a repeat intravenous urogram.

reduced in three of the five patients, and two patients had congenital structural abnormalities.

Since there was a significantly greater number of mildly affected patients among the 30 new patients $\left(y^{2}=6.67 ; p<0.01\right)$ we performed a subgroup analysis comparing the severe and moderately affected patients in the two groups (table V). None of the differences between the follow-up and new moderately or severely affected patients was significant.

TABLE V-Subgroup analysis: comparison of variables in patients with moderate/ severe haemophilia excluding mildly affected patients

\begin{tabular}{|c|c|c|}
\hline & $\begin{array}{l}\text { No }(" .) \text { of } \\
\text { patients } \\
\text { followed up } \\
\text { since 1969 } \\
(\mathrm{n}=23)\end{array}$ & $\begin{array}{l}\text { No }(\%) \text { of } \\
\text { new patients } \\
(\mathrm{n}=16)\end{array}$ \\
\hline $\begin{array}{l}\text { Haematuria } \\
\text { Abnormal creatinine clearance rate }(<80 \mathrm{ml} / \mathrm{min} \text { ) } \\
\text { Abnormal intravenous urogram (including } 1 \text { CT scan) }\end{array}$ & $\begin{array}{r}17(74) \\
4(17) \\
8(35)\end{array}$ & $\begin{array}{l}8(50) \\
1(6) \\
2(13)\end{array}$ \\
\hline
\end{tabular}

\section{Discussion}

This study of renal function in haemophilia has produced a number of clinically important findings. Although much emphasis in the past has been placed on a history of haematuria, we have found it to be a poor indicator of the incidence and severity of renal abnormalities. No demonstrable radiological abnormality was found in two patients with a history of severe haematuria, while $43 \%$ of patients with mild haematuria and $15 \%$ of patients with no history of haematuria had a documented abnormality. The study has also confirmed that haematuria is a fairly common complaint, occurring in $67 \%$ of the follow-up group and $40 \%$ of the newly investigated group. In total, 21 $(37 \%)$ of our patients admitted to taking regular analgesics, which may be an underestimate, but only one of the 55 intravenous urograms showed evidence of analgesic nephropathy. At least one previous case of analgesic nephropathy has occurred in a haemophiliac ingesting large quantities of phenacetin. ${ }^{4}$

Hypertension, despite the high incidence of renal abnormalities, seemed to occur with a frequency in our patients equivalent to that in the general population, and although four patients had increasing age of the haemophilic population, ${ }^{6}$ but the results from both the new and follow-up group do not support this theory. Nephromegaly has been noted in patients with haemophilia, ${ }^{7}$ and the workers postulated that multiple transfusions might have been the cause as it has also been found in other groups of patients with such diseases as thalassaemia and sicklecell anaemia, in whom multiple transfusions are common. In our self-treated patients, some of whom received regular prophylaxis and therefore large amounts of plasma concentrates, no case of nephromegaly was found.

We have also confirmed our previous findings that infection is uncommon despite these anatomical abnormalities, that congenital abnormalities occur commonly ( $9 \%$ of our group had partial or complete duplex systems), and that isotope renography is a simple and highly sensitive screening test of renal abnormality in these patients

Despite the high incidence of structural renal tract abnormalities and the evidence for diminished renal function in a few patients, clinically important renal disease has not been found. The natural history of renal tract bleeding in haemophilia is probably benign and does not lead to progressive renal failure.

We wish to thank Sister A Ward for her help during this study and Dr G D O Lowe for advice during the preparation of the manuscript.

\section{References}

${ }^{1}$ Rizza CR, Matthews JM. Management of the haemophiliac child. Arch Dis Child 1972;47:451-62.

2 Prentice CRM, Lindsay RM, Barr RD, et al. Renal complications in haemophilia and Christmas disease. $Q \mathcal{F}$ Med 1971;40:47-61.

${ }^{3}$ Dholakia AM, Howarth FH. The urinary tract in haemophilia. Clin Radiol 1979;30:533-8.

4 Wright FW, Matthews JM, Brock L. Complications of haemophiliac disorders affecting the renal tract. Radiology 1971;98:571-6.

5 Beck P, Evans KT. Renal abnormalities in patients with haemophilia and Christmas disease. Clin Radiol 1972;23:349-54.

${ }^{6}$ Forbes CD, Prentice CRM. Renal disorders in haemophilia A and B. Scand $\mathcal{F}$ Haematol 1977;30 suppl:43-50.

? Dalinka MK, Lally JF, Rancier LF, Mata J. Nephromegaly in haemophilia. Radiology 1975;115:337-40.

(Accepted 20 September 1982) 